\title{
THE FRANCO-BRAZILIAN NETWORK ON NATURAL PRODUCTS (FB2NP): A NEW NETWORK PROMOTING COOPERATION AND EXCHANGES IN NATURAL PRODUCTS RESEARCH
}

Brazil and France share a long and fruitful scientific partnership made of friendship, fascination, admiration, and cooperation. The writings of the first French visitors to Brazil, André Thevet (1557), Jean de Léry (1580) and Claude d'Abbeville (1614), emphasize their astonishment and wonder at discovering the Brazilian people, landscapes and the richness diversity of the Brazilian natural resources. $^{1-3}$

Their first reports marveled at the immense animal and plant biodiversity and also mentioned the traditional use of local natural products for food, clothing, social and cultural ceremonies of local tribes. Following the rise and development of the "natural sciences" from the $18^{\text {th }}$ to the $21^{\text {st }}$ century, France and Brazil have progressively developed scientific and academic cooperation characterized by strong, long-standing, and structured links, forming part of a strategic partnership between the two countries. These relations have played a key role in the modernization of both countries and have contributed to improving the living conditions of their populations since the $18^{\text {th }}$ century. Indeed, scientific discoveries with mutual societal benefits have been numerous in the fields of humanities, ethnology, botany, pharmacognosy, infectiology, parasitology, physiology, surgery, medicine, chemistry, physics and mathematics. ${ }^{4}$

In the beginning of this cooperation, scientific contacts between France and Brazil were mainly devoted to the description of the populations, fauna, flora and resources of Brazil, in the naturalist tradition of the European Enlightenment and colonialist vision of resources valorization. For example, the French explorers CharlesMarie de la Condamine (1701-1774) and Auguste de Saint-Hilaire (1779-1853) traveled into Brazil for months and their major contributions were to the knowledge and description of Brazilian botany and zoology. Later, the Brazilian emperor Pedro II (18251891) took several initiatives to stimulate Franco-Brazilian scientific communication and to import and spread French science in Brazil. Among his achievements, Brazil adopted the metric system developed in France and participated in the first international metric convention held in Paris in $1875 .^{5}$

In 1876, the Escola de Minas de Ouro Preto (Minas Gerais, Brasil) was created on the model of the Ecole Nationale Supérieure des Mines de Saint-Etienne (Ecole des Mines de Saint-Étienne) and the French geologist Claude Henri Gorceix (1842-1919) and his assistants Armand de Bovet and Arthur Thizé were invited to this school. Pedro II also invited Louis Pasteur and Claude Bernard to visit Brazil to spread their microbiology and physiology discoveries. Although Pasteur did not visit Brazil, he took the time to travel to Bordeaux to examine yellow fever parasites coming from Brazilian ports. Louis Couty, Claude Bernard's assistant, arrived in Brazil in 1880 to work in the experimental physiology laboratory of the Brazilian National Museum in Rio, in collaboration with João Baptista de Lacerda (1846-1915), a famous Brazilian physiologist. This laboratory is considered the oldest scientific institution created in Brazil and the first experimental laboratory in South America. ${ }^{5}$

Pedro II was a corresponding member and later a foreign associate member of the Paris Academy of Sciences and he confirmed his admiration for Pasteur by making a personal donation to contribute the creation of the Pasteur Institute in Paris. A few years later, a mission of Pasteur Institute researchers led by Emile Marchoux went to Brazil to support the government evaluate operations to combat yellow fever. In 1896, the Pasteur Institute welcomed the young hygienist Oswaldo Cruz. After his stay for training in Paris, Cruz returned to Brazil where he created the Federal Institute of Serotherapy, which later successively turned the Instituto Oswaldo Cruz and Fundação Oswaldo Cruz., ${ }^{5,6}$

Inaugurated in 1900, the Instituto Oswaldo Cruz became famous for its expertise in parasitology and infectiology, under the impulse of its different heads, such as Carlos Chagas, Henrique Aragão and Olympio da Fonseca. Cruz's action was decisive in contributing to the eradication of yellow fever and smallpox in Brazil, especially in Rio, between 1903 and 1907.

In the wake of these eminent predecessors, the $20^{\text {th }}$ century saw the structuring of the Franco-Brazilian scientific community around courses and projects of excellence between universities and through high-level research colaborations.

As early as the 1930s, Fernand Braudel, Claude Lévi-Strauss and Roger Bastide worked to forge strong academic ties between France and Brazil by participating in the founding of the Universidade de São Paulo (USP), today one of the most prestigious Latin America university. This period was very active and fruitful, with the foundation of the CNPq in 1951, the creation of Franco-Brazilian institutes, and the invitation, exchange and recruitment of renowned scientists and physicians in French and Brazilian universities. ${ }^{5}$

Technical and scientific cooperation agreements were signed between research institutes such as CNRS, CEA, IRD, INSERM, CNPq, the Polytechnic School of Rio de Janeiro, the Universidade de São Paulo and the Pasteur Institute. The 1970s were also a period of structuring of Franco-Brazilian networks and in 1978, with the creation of the CAPES-COFECUB program, a balanced partnership of high scientific quality. ${ }^{7}$ To date, the CAPES-COFECUB program already trained nearly 3,000 Brazilian PhDs in different scientific fields.

In 2012, the Guyamazon program was founded to support scientific partnerships and cross-border research between universities in the northern states of Brazil and French Guiana on topics related to the Amazon issue. Thanks to these close ties, nowadays France is Brazil's leading European research partner, even before Portugal. France is also the world's third largest destination for Brazilian students and the number of French students coming to Brazil is the largest among foreign students. In terms of scientific co-publications, France is Brazil's second largest partner (after the United States) and the largest foreign investor in Brazil, with more than 500,000 jobs in French companies operating in the country.

The CNRS, IRD (Institut Français de Recherche et de Développement), and CIRAD (Centre Français de Coopération Internationale en Recherche Agronomique pour le Développement) representations in Brazil are very active and contribute strongly to the development of structuring partnerships between the two countries, notably through the implementation of joint research programs. Joint programs for innovative technologies have also seen significant developments since the middle of the $20^{\text {th }}$ century, following investments in cooperative research and development programs.

In the field of research on natural products, France and Brazil have serious assets and skills to share. Brazil, with a territorial area 
of 8,511,996 km² and an Atlantic coastline of 7,491 km, is one of the richest countries in biodiversity in the world. It contains $10-20 \%$ of the known living species and it is estimated that a significant number remain to be discovered and evaluated for their pharmacological potential. ${ }^{8,9}$

Approximately 2 million species of plants, animals, and microorganisms have been described in the six Brazilian biomes: the Amazon rainforest in the north, the coastal Atlantic forest, the savanna (Cerrado) zone in the center of the country, the semi-arid zone in the northeast (Caatinga), the wetlands in the center-west (Pantanal), and the Pampa fields in the south. ${ }^{10}$

With Guiana, France shares its longest border with Brazil and also has access to one of the richest departments in the world in terms of animal and plant biodiversity. Thus, the Brazilian and French natural resources can represent an important field of investigation for pharmacology, pharmacognosy, toxinology, medicinal chemistry, and biotechnology. In addition, Brazilian traditional medicine also represents a rich cultural heritage for the discovery of original and innovative bioactive natural products that could be sustainably developed for the benefit of local populations.

Another positive point is that in France there are several networks of researchers in the area of natural products that work in partnership with Brazilian researchers. These include, for example, the French and Brazilian societies of pharmacology and therapeutics, the societies of pharmacognosy, the international society of applied phycology, the French and Brazilian societies of chemistry, the Group for the Promotion of Pharmaceutical Chemistry in Academia (GP2A), the French Medicinal Chemistry Society (SCT), research groups (GDR) in chemistry, cosmetics, pharmacy, marine drugs, and partners working in national or international networks financed at the regional, interregional, national or international levels (Cancéropôles, competitiveness clusters, regional funds, ANR programs of the French National Research Agency, interregional European programs, etc.).

Sharing their skills, expertise, equipments, and linking these networks a synergistic work on developing new collaborative and cutting-edge research projects will be improved. In a context of globalization of research and restriction of funds, it is indeed important that French and Brazilian scientific community continues its development with the objective of meeting the challenges of excellence, internationalization, pooling of resources and interaction with the private sector and civil society. Another important priority is to promote access to higher education for French and Brazilian students and to increase the scientific quality of public and private universities.

In this context, the creation of the French-Brazilian Network on Natural Products FB2NP is logically in line with a vision of structuring research to achieve these objectives and strengthen the partnership and contacts between research centers and French and Brazilian universities. In November 2021, the FB2NP network includes more than thirty laboratories with shared interests in various areas of natural products research, including chemical characterization of medicinal and food plants, algae, fungi and bacteria, pharmacological evaluation of natural products against bacteria, cancer cell lines, inflammation, pain models, and as inhibitors of disease-related protein kinases, synthesis and pharmacomodulation of drugs inspired by terrestrial and marine bioactive natural products. (Figure 1).

The network partners are also developing innovative methodologies for the extraction, isolation, and analysis of natural products or environmental samples, using new and original approaches in metabolomics, environmental scanning electron microscopy, environmentally friendly extraction and purification processes and screening facilities for bioactive drug identification (e.g., centrifugal partition chromatography, chemical ecology and metabolomics, protein kinase inhibitor screening platform, cancer

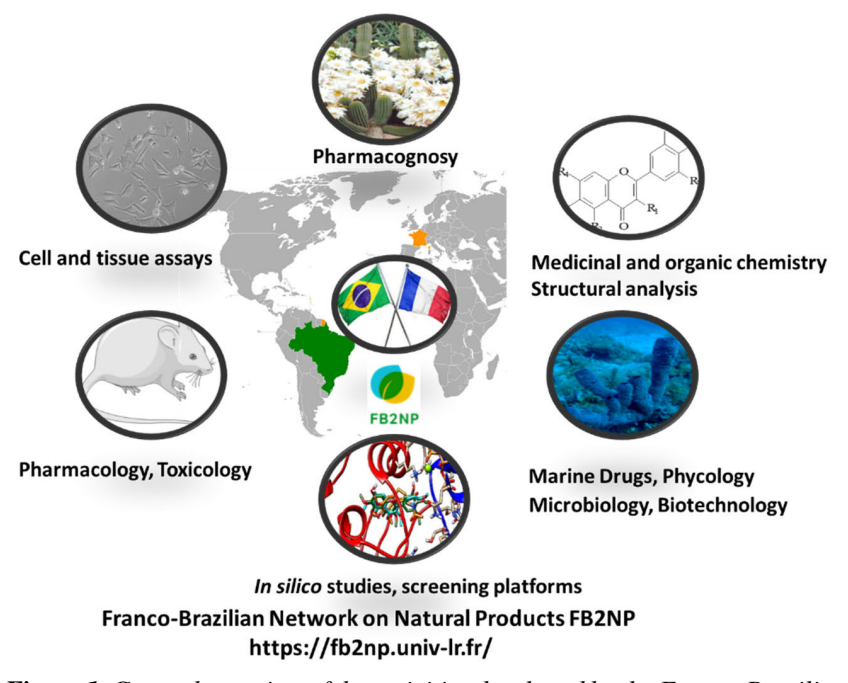

Figure 1. General overview of the activities developed by the Franco-Brazilian Network on Natural Products

cell and animal model culture facilities, microwave-assisted organic synthesis and extraction platforms, etc.).

The major potential of the network is that of human resources, with more than 600 interconnected researchers distributed in the Brazilian states and French regions. Although the network was created very recently, the first actions have already demonstrated the real added value of working together. These include the invitation of French researchers to participate in the Brazilian Symposium of Pharmacognosy, the hosting of Brazilian masters and PhD students in French laboratories, for a full thesis period or co-tutorials, exchanges of French and Brazilian academic researchers, the signature of university partnership agreements, the request and obtaining of research funds for research projects including Franco-Brazilian partners, the joint participation in international congresses, and the organization of webinars.

A preliminary website (https://fb2np.univ-lr.fr/) was also created for the FB2NP network and it is currently being updated. It should be updated regularly as new French and Brazilian teams join the consortium. An important step has also been taken with the identification of the FB2NP network in the Scopus and Pubmed bibliographic databases, and network partners are invited to add this affiliation in their publications to highlight their membership in the network.

The next step will be to obtain funding for larger-scale projects that could be managed by a consortium of teams identified through an internal call for projects. The network is intended to be a lively and dynamic structure, organizing webinar sessions, regular meetings, and shared sessions for students and researchers to stimulate training in advanced techniques. The network will also allow researchers to share their views and opinions on areas of cutting-edge innovation in the field of natural products, and to inform the community of the latest developments in the field.

The internal structuring of the network could also include the regular election of a scientific committee, the nomination of an honorary president and the attribution of thesis prizes and participatory funding to support the participation of students in international conferences. Finally, the FB2NP partners hope that this initiative will be supported by public research funders in Brazil and France and that the capitalization of the FB2NP results will lead to the creation of spin-off or start-up companies or the participation of private partners in the network.

In conclusion, FB2NP reflects the determination of Brazilian and French researchers to keep alive and strengthen the long and fruitful tradition of scientific cooperation in natural products research, to take 
up together the challenges of excellence, internationalization and mutualization of competences, and to resist the economic or political hazards, which seem less difficult to overcome in a united consortium.

Jackson Roberto Guedes da Silva Almeida Núcleo de Estudos e Pesquisas de Plantas Medicinais, Universidade Federal do Vale do São Francisco e-mail: jackson.guedes@univasf.edu.br

Raphaël Grougnet ${ }^{\mathbb{1}}$

Université de Paris

e-mail: raphael.grougnet@parisdescartes.fr

Lucindo José Quintans Junior ${ }^{(0)}$ Department of Physiology, Universidade Federal de Sergipe e-mail: lucindojr@gmail.com

Sylvie Chevalier

Université de Rouen

e-mail:sylvie.chevalier@univ-rouen.fr

Marc Feuilloley ${ }^{(1)}$

Université de Rouen

e-mail:marc.feuilloley@univ-rouen.fr

Thomas Robert

Sorbonne Université e-mail: thomas.robert@sb-roscoff.fr

Stéphane Bach ${ }^{(1)}$

Sorbonne Université e-mail: bach@sb-roscoff.fr

Raimundo Gonçalves de Oliveira Junior ${ }^{(1)}$ Núcleo de Estudos e Pesquisas de Plantas Medicinais, Universidade Federal do Vale do São Francisco e-mail: oliveira.farma.junior@gmail.com

Valérie Thiéry

La Rochelle Université e-mail:valerie.thiery@univ-lr.fr

Jean-Pierre Bazureau

Université de Rennes 1 e-mail: jean-pierre.bazureau@univ-rennes1.fr

Florence Mongin

Université de Rennes 1 e-mail: florence.mongin@univ-rennes1.fr

Marina Kritsanida ${ }^{(1)}$

Université de Paris e-mail: marina.kritsanida@parisdescartes.fr
Vincent Sol ${ }^{\circledR}$

Université de Limoges e-mail:vincent.sol@unilim.fr

Vicente Carlos de Oliveira Costa

Universidade Federal da Paraíba e-mail:vicentejpa@gmail.com

Nathalie Bourgougnon Université de Bretagne Sud e-mail: nathalie.bourgougnon@univ-ubs.fr

Pascal Marchand

Université de Nantes e-mail: pascal.marchand@univ-nantes.fr

Laurent Picot

La Rochelle Université e-mail: laurent.picot@univ-lr.fr

\section{REFERENCES}

1. Thévet, A.; Les singularitez de la France antarctique, reed. 1878, with notes and comments by Paul Gaffarel, Paris, 1878.

2. de Léry, J. ; Histoire d'un voyage fait en la terre du Bresil, autrement dite Amerique. Containing the navigation, and remarkable things, seen on sea by the author. The behavior of Villegagnon in this country. The manners and strange ways of living of the American Indians: with a colloquy of their language. Together the description of several Animals, Trees, Herbs, and other singular things, and unknown at all there: of which one will see the summaries of the chapters at the beginning of the book. All collected on the spot by Jean de Lery, native of Margelle, land of sainct Sene, in the Duchy of Bourgogne, La Rochelle or Geneva, Antoine Chuppin, 1578.

3. d'Abbeville, C.; Histoire de la mission des pères Capucins en l'Isle de Maragnan et terres circonvoisines, 1614.

4. Tettamanzi, R.; Le voyage au Brésil, Anthologie de voyageurs Français et Francophones du XVI İme au XX ìme siècle, Robert Laffont: Paris, 2014.

5. France-Brazil: twenty years of cooperation; Cardoso, L. C., Martinière, G., dir.; A personal vision of the scientific cooperation between France and Brazil, from 1758 to 1966, Carlos Chagas, pp 26-30, Editions de l'IHEAL Institut des Hautes Etudes de l'Amérique Latine, available at https://books.openedition.org/iheal/1696?lang=fr (in French), accessed at November 2021.

6. Fiocruz, available at https://portal.fiocruz.br/en, accessed at November 2021.

7. CAPES-COFECUB, available at https://www.campusfrance.org/fr/ capes-cofecub, accessed at November 2021.

8. Bolzani, V. S.; Valli, M.; Pivatto, M.; Viegas, C.; Pure Appl. Chem. 2012, 84, 1837.

9. Valli, M.; Santos, R. N.; Figueira L. D.; Nakajima C. H.; Castro-Gamboa I.; Andricopulo, A. D.; Bolzani, V. S.; J. Nat. Prod. 2013, 76, 439.

10. Valli, M.; Pivatto, M.; Danuello, A.; Castro-Gamboa, I.; Silva, D. H. S.; Cavalheiro, A. J.; Araújo, A. R.; Furlan, M.; Lopes, M. N.; Bolzani, V. S.; Quim. Nova 2012, 35, 2278. 